\title{
An Analysis of Student's Mathematical Literacy Ability of Junior High School Students
}

\author{
Pangestika Sumadianing Saputri \\ Department of Mathematics \\ Education \\ Universitas Sebelas Maret \\ Surakarta, Indonesia \\ pangestikasaputri@gmail.com
}

\author{
Mardiyana \\ Department of Mathematics \\ Education \\ Universitas Sebelas Maret \\ Surakarta, Indonesia \\ mardiyana@staff.uns.ac.id
}

\author{
Triyanto \\ Department of Mathematics \\ Education \\ Universitas Sebelas Maret \\ Surakarta, Indonesia \\ triyanto@fkip.uns.ac.id
}

\begin{abstract}
This research aims to describe the ability of student's mathematical literacy consisting of four contents, namely space and shape, change and relationship, quantity, and uncertainly. Next, it is defined on which the lowest content of student's ability, how the perform of students on the process of literacy and basic skills of mathematics, and what causes students are not able to provide correct answers to the certain problem. By knowing where the weaknesses of students on certain mathematical literacy content will make us better know which content should be more taught. This research used the qualitative descriptive method, with research subjects consisting of six students of class VII SMP Negeri 2 Pacitan which selected using purposive sampling. The instruments which used to explore the ability of mathematical literacy of students in the form of written tests followed by interviews. The results showed the ability of mathematical literacy in term of space and shape content of $13.3 \%$; content change and relationships of $21.4 \%$; content quantity of $36 \%$; and uncertainly content of $29.3 \%$. The percentages were obtained based on the student's answers at the time of the test and reinforced by interviews. It is shown that the student's mathematical literacy ability on space and shape content is the lowest. Students were not able to do the literacy process yet, that was formulate, employ, and interpret on the content space and shape. In the context of basic mathematics skills, most students were only able to meet the communication and devising strategies. Students were not able to provide correct answers to mathematical literacy context on space and shape because students did not understand the given problem or the students understood the given problem but the students could not use the right strategy in solving the problem.
\end{abstract}

Keywords-mathematical literacy, mathematical literacy content, space and shape

\section{INTRODUCTION}

Living in the era of globalization closely related to the development of science, technology, and art that requires the society to survive and learn throughout life. Various efforts following the demands of globalization, one of them is through literacy. "Literacy for All", is one of the slogans called by the United Nations, Educational, Scientific, and Cultural Organization (UNESCO). Regarding to this term, literacy for all is at the heart of basic education for all [1]. Creating literate environments and societies is essential in order to achieve the goals of eradicating poverty, reducing child mortality, curbing population growth, achieving gender equality and ensuring sustainable development, peace and democracy. It is evident that a vital component of the right to education is literacy; not only as a tool, but as a right that helps achieve the fulfillment of this universal human right, the full development of the person, and therefore, the possibility of enjoying and exercising all other human rights.

In line with the goal of technological development, to achieve technological development, capability of human must be developed through mathematical literacy [2]. If a student possesses a mathematical literacy skill, then the student can prepare himself in association with modern society [3]. The reason is mathematics is not only viewed as a discipline of science, but how students can apply the knowledge in real word problems. De Lange mentioned that the word literacy is related to a real problem, that is a problem which is not pure mathematics [4].

PISA 2012 defined that mathematical literacy is an individual's capacity to formulate, employ, and interpret mathematics in a variety of contexts. It includes mathematical concepts, procedures, facts and tools to describe, explain and predict phenomena. It assists people to construct, engage and reflect citizens [3]. In short, Ojose argues that mathematical literacy is the knowledge to know and use basic mathematics in everyday life [5]. It means that a person with good mathematical literacy skills has sensitivity toward which mathematical concepts that relevant to the phenomena or problems faced. 
PISA 2012 defined a model of mathematical literacy in practice. Mathematical literacy as a challenge in a real-world context consists of four math contents, namely space and shape, change and relationships, quantity, and uncertainly and realworld context categories that are personal, social, occupational, and scientific. Mathematical literacy as a mathematical thought and action consists of mathematical concepts, knowledge, and skills; basic math skills is communication, representation, devising strategies, mathematizing, reasoning and argument, using symbolic, formal and technical language and operations, and using mathematical tools; and processes are formulate, employ, and interpret/evaluate [3]. The contents of mathematical literacy namely, space and shape relate to geometric matter; change and relationship with regard to algebra material; quantity relating to relative size, pattern recognition of numbers, and the use of numbers; and uncertainly deals with problem solving on data and probabilities [6].

Regarding to content, that content taught in school mathematics should reflect relevance to society [5]. The importance of mathematical literacy analysis in mathematics learning is to provide an overview for teachers in order to design literacy-based learning and to familiarize students with literacy-based questions, which will train students to solve math problems in everyday life and to give students sensitivity to phenomena mathematically around them. By knowing where the weaknesses of students on certain mathematical literacy content will make us better know which content should be more taught.

Based on the description above, this study aims to describe student's mathematical literacy skills. The description is based on four mathematical literacy contents namely space and shape, change and relationship, quantity, and uncertainly. Next, it is defined on which the lowest content of student's ability, how the perform of students on the process of literacy and basic skills of mathematics, and what causes students are not able to provide correct answers to the certain problem.

\section{RESEARCH METHOD}

This type of research was qualitative descriptive. The qualitative research is a study which intends to understand the phenomenon of what is experienced by research subjects, such as behavior, perception, motivation, action, etc, holistically and by way of description in the form of words and language, in a special, natural context and by utilizing various scientific methods [7]. This research was made to analyze and describe student's mathematical literacy ability on four contents of literacy.

The research was conducted on April 2, 2018 until May 15, 2018. The subjects in this study consisted of six students of class VII SMP Negeri 2 Pacitan selected using purposive sampling. The research instruments used to explore the ability of mathematical literacy in the form of written test followed by interviewes. The test instrument consists of 5 items that contain space and shape, change and relationship, quantity, and uncertainly. Futhermore, interviews were made of the six students based on the results of their works. Interviews were used in the form of semi-structured interviews, in which questions developed during the interview process. This interview was conducted to extract information that can not be obtained by researchers from the test results. The validity test of data which used in this research was triangulation technique. Triangulation method and triangulation of data were used in this research, that was by checking the data from the test result with the data of interview. The steps which taken in this research were 1) the researcher randomly choosed one class in SMP Negeri 2 Pacitan; 2) the researcher gave the math literacy test; 3 ) analyzed the test results; 4) conducting interviews on selected subjects by purposive sampling.

\section{RESULTS AND DISCUSSION}

Initial stages in this research was used to arrange math literacy test which consisted of four contents, namely space and shape, change and relationship, quantity, and uncertainly. The tests were structured in term of real-world context categories: personal, social, occupational, and scientific; basic math skills ie communication, representation, devising strategies, mathematizing, reasoning and argument, using symbolic, formal and technical language and operation, using mathematical tools; processes are formulated, employ, and interpret/evaluate. The explanation of four literacy contents as seen in the Table 1 [6].

TABLE I. MATHEMATICAL LITERACY CONTENT

\begin{tabular}{|l|l|}
\hline \multicolumn{1}{|c|}{ Literacy Content } & \multicolumn{1}{c|}{ Indicators } \\
\hline Space and shape & $\begin{array}{l}\text { Looking for similarities and differences, } \\
\text { recognising shapes in different } \\
\text { representations and different dimensions, } \\
\text { understanding the properties of objects and } \\
\text { their relative positions, and the relationship } \\
\text { between visual representations (both two } \\
\text { and three dimensional) and real objects. }\end{array}$ \\
\hline \multirow{5}{*}{ Change and relationship } & $\begin{array}{l}\text { Recognising relationships between } \\
\text { variables and thinking about relationships } \\
\text { in a variety of forms including symbolic, } \\
\text { algebraic, graphical, tabular and geometric. }\end{array}$ \\
\hline \multirow{3}{*}{ Uncertainly } & $\begin{array}{l}\text { Understanding of relative size, recognition } \\
\text { of numerical patterns, and the use of } \\
\text { numbers to represent quantities and } \\
\text { quantifiable attributes of real world objects } \\
\text { (counting and measuring). }\end{array}$ \\
\hline & $\begin{array}{l}\text { Solving problems related to data and } \\
\text { chance, which generally correspond to } \\
\text { statistics and probability in school } \\
\text { curricula. }\end{array}$ \\
\hline
\end{tabular}


After the mathematical literacy test was conducted, the test results showed that most students were able to solve the problem in scope of change and relationship, quantity, and uncertainly. Only a small percentage of students are able to solve the problem on space and shape content. Student's mastery of mathematical literacy content can be seen in Fig. 1 as follows.

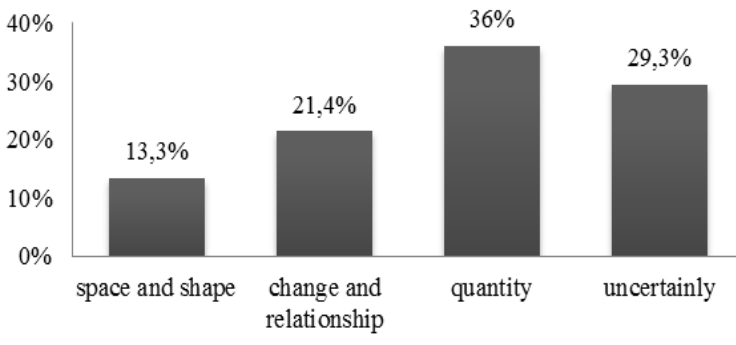

Fig. 1. The percentage of student's mastery over mathematical literacy content

The percentage of students who were able to solve the problems in each mathematical literacy content, namely space and shape, change and relationship, quantity, and uncertainly were $13.3 \%$, respectively; $21.4 \%$; $36 \%$; and $29.3 \%$. The results showed that student's mathematical literacy skills were low on space and shape content. This can be seen in the sample of student's work which are as follows.

Seorang tukang ingin memasang plafon rumah dengan bahan triplek. Ukuran luas satu triplek adalah $5 \mathrm{~m}^{2}$. Triplek besar dipotong-potong pengganti asbes berbentuk persegi dengan panjang sisi $\frac{1}{2} \mathrm{~m}$. Berapa banyak asbes yang dapat dibuat dari satu triplek besar?

Fig. 2. Space and shape content

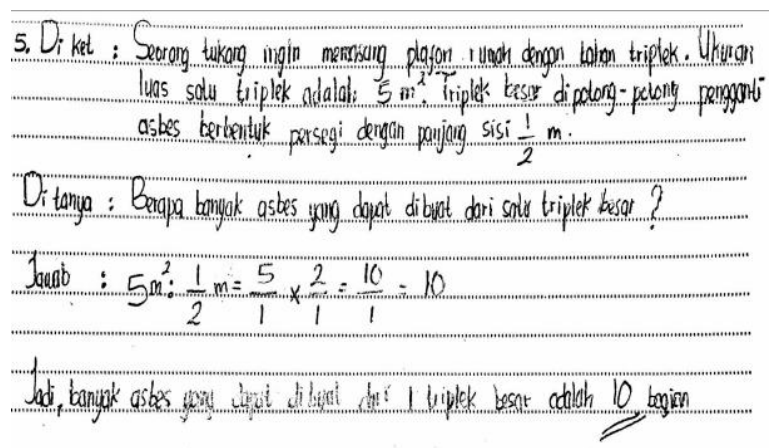

Fig. 3. S1 Answer

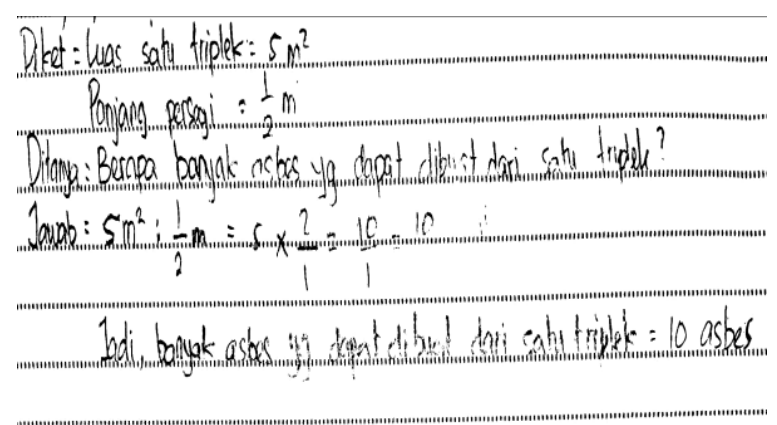

Fig. 4. S2 Answer

The results of $\mathrm{S} 1$ and $\mathrm{S} 2$ answers above indicated that students could write what was known and what was asked, students could formulate, but they could not apply and interpret what was obtained from the problem. In basic mathematics skills such as communication, representation, devising strategies, mathematizing, reasoning and argument, using symbolic, formal and technical language and operations, and using mathematical tools, students are able to perform formal and technical language and operation and communication at the end of the problem is writing the conclusion of the answer. Students were able to use the strategy to solve the problem, but the strategy used was not right, they also did not use illustration to make easy in answering the problem/question so that the answers which were from $\mathrm{S} 1$ and $\mathrm{S} 2$ tend to be wrong. The results of S1 and S2 answers tend to be the same, the only difference lies in the writing of mathematical form only. Based on the results of interviews, S1 and S2 understood the problem given, but they were less careful in doing the problem. They should calculated the square area first, before being used to divide the entire known area. Student error lies only in the use of inappropriate strategies.

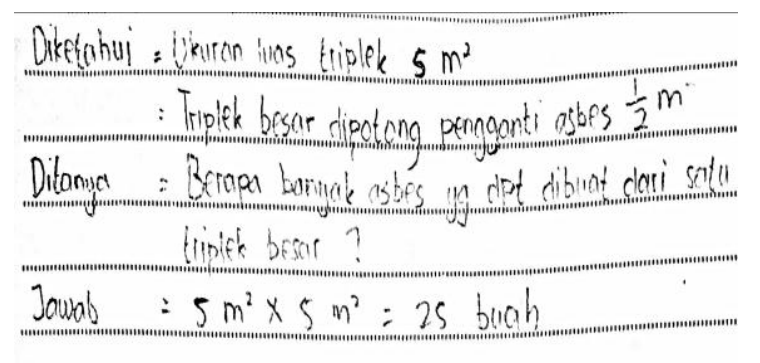

Fig. 5. S3 Answer

The S3 result above, students could write down what was known and asked as question or problem which to be solved, but students could not formulate, apply and interpret what was obtained from the problem. Even for basic math skills is communication, representation, devising strategies, mathematizing, reasoning and argument, using symbolic, formal and technical language and operation, using mathematical tools, students did not reached it yet. Students have difficulties and they could not use strategies to solve problems. They also 
did not use illustration to make them easier to answer the problems.

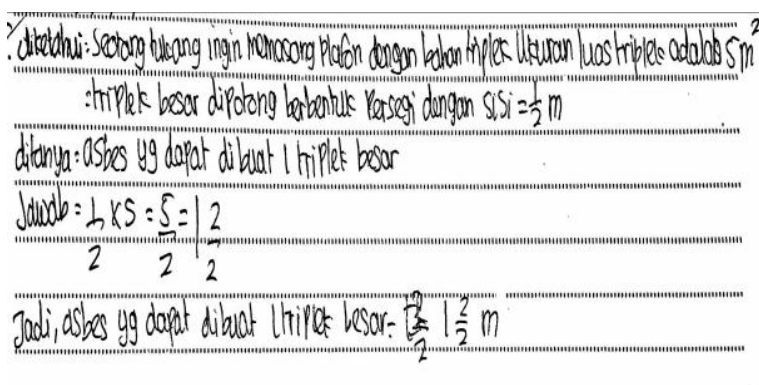

Fig. 6. S4 Answer

In the results of S4, students could formulate, but they could not apply and interpret what was obtained from the question. Students were able to perform communication at the end of work, namely writing the conclusion of the answer. But they are not able to use strategies to solve problems, students also did not use illustration to make them easy to answer the problem. The answers from S3 and S4 tend to be wrong.

Based on the results of S3 and S4 interviews, they did not understand the given problem, so they are wrong in determining the strategy that should be used to solve the problem. Mistakes in the strategy of causing the answers S3 and S4 also tended to be wrong. S3 and S4 also could not transform the problem into mathematical form, this causes them can not illustrate the illustration of the given problem. Though illustrations were useful to facilitate the working of the problem.

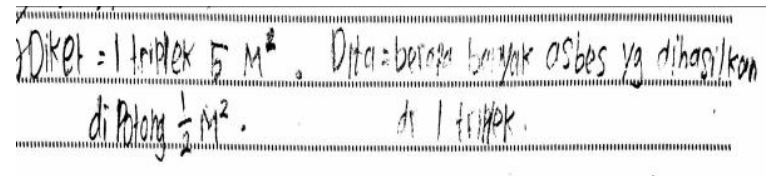

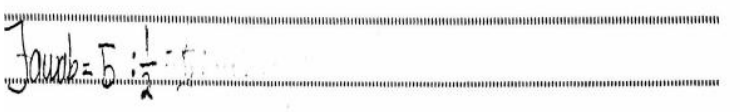

Fig. 7. S5 Answer

In the answer of S5 above, students could write what is known and asked as questions, but they could not formulate, employ and interpret what was obtained from the problem. The answer was that the students did not continue what had been written. Based on the interview, S5 did not understand the given problem. They could not even decide which strategy to use in working on the problem. S5 could not write down their answers.

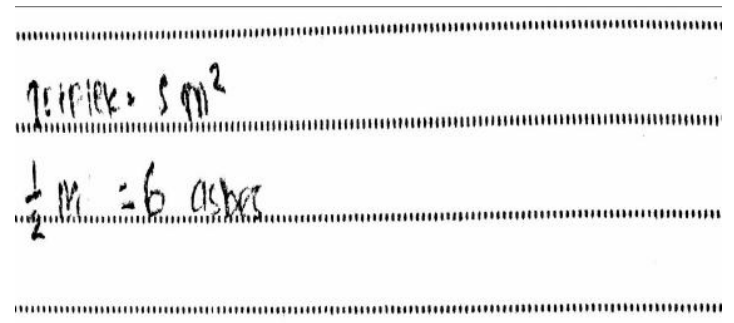

Fig. 8. S6 Answer

In the result of S6 answer, students did not write what was known and asked. Students were also not clear in writing the answers. Based on the interview, S6 did not understand the given problem. They could not even decide which strategy to use in working on the problem. S6 could not write down their answers.

The finding in this study showed that the students were not able to do the process of literacy, namely formulate, employ, and interpret on the content of space and shape. In the context of basic mathematics skills, students were not able yet to fulfill all basic mathematical abilities consisting of communication, representation, devising strategies, mathematizing, reasoning and argument, using symbolic, formal and technical language and operations, and using mathematical tools. Most students were only able to meet the communication and devising strategies. In addition, what was interesting to be discussed was the lowest percentage of student's correct answer toward the space and shape content. This was like the result of a study conducted by Maulana and Hasnawan which compared the achievement of student's mathematics literacy skills based on the tested content, the highest score achieved by the students was on change and relationship content, while the lowest score achieved by the students was on the space and shape content [8]. The finding showed that the student's inability to provide answers to the math literacy, especially problem in space and shape. The student's inability to provided answers to mathematical literacy context on space and shape because students did not understand the given problem or the students understood the given problem but the students could not use the right strategy to solve the problem.

\section{CONCLUSION}

Based on the results of data analysis of this study, it can be concluded that the student's mathematical literacy ability

in four mathematical literacy contents, namely space and shape, change and relationship, quantity, and uncertainly were $13.3 \% ; 21.4 \% ; 36 \%$; and $29.3 \%$. The ability of student's mathematical literacy on the space and shape content was the lowest. Students were not able to do the literacy process yet, that was formulate, employ, and interpret on the content space and shape. In the context of basic mathematics skills, 
students were not able to fulfill all basic mathematical abilities consisting of communication, representation, devising strategies, mathematizing, reasoning and argument, using symbolic, formal and technical language and operation, and using mathematical tools. Most students were only able to meet the communication and devising strategies. Students were not able to provide correct answers to the problem of space and shape math literacy content because students did not understand the given problem or students understood the given problem but the students could not use the right strategy in solving the problem.

\section{REFERENCES}

[1] G. A. S. Moretti and T. Frandell, Literacy from a Right to Education Perspective. Report of the Director General of UNESCO to the United Nations General Assembly 68th Session, 2013.
[2] O. B. Adeyemi and M. O. Adaramola, "Mathematics Literacy as a Foundation for Technological Development in Nigeria," Journal of Research and Method in Education, vol. 4, pp. 2831, September-October 2014.

[3] OECD, PISA 2012 Results: What Students Know and Can Do - Student Performance in Mathematics, Reading and Science. Paris: OECD Publishing, 2014.

[4] J. de Lange, "Mathematical Literacy for Living from OECDPISA Perspective," Tsukuba Journal of Educational Study in Mathematics, vol. 25, pp. 13-35, 2006.

[5] B. Ojose, "Mathematics Literacy: Are We Able To Put The Mathematics We Learn Into Everyday Use?" Journal of Mathematics Education, vol. 4, pp. 89-100, June 2011.

[6] S. Thomson, K. Hilman, and L. D. Bortoli, A Teacher's Guide to PISA Mathematical Literacy. Australia: ACER Press, 2013.

[7] L. J. Moleong, Metode Penelitian Kualitatif. Bandung: Remaja Rosdakarya, 2013

[8] A. Maulana and Hasnawati, "Description of Mathematics Literacy Ability of Students at VIII-2 Grade of SMP Negeri 15 Kendari," Jurnal Penelitian Pendidikan Matematika, vol. 4 , $\mathrm{pp}$ $1-14$, 2016. 